\title{
REVAMPING SOIL QUALITY AND CORRELATION STUDIES FOR YIELD AND YIELD ATTRIBUTES IN SORGHUM-LEGUMES INTERCROPPING SYSTEMS
}

\author{
MELHORIA DA QUALIDADE DO SOLO E ESTUDOS DE CORRELAÇÃO PARA A \\ PRODUTIVIDADE E OS ATRIBUTOS DE PRODUTIVIDADE EM SISTEMAS DE \\ PLANTIO CONSORCIADO DE SORGO E LEGUMES
}

\author{
Muhammad Aamir IQBAL ${ }^{1}$; Asif IQBAL ${ }^{2}$ Zahid MAQBOOL ${ }^{3}$; Zahoor AHMAD ${ }^{4}$; Essa ALI'; \\ Muzammil H. SIDDIQUI ${ }^{1}$; Sajid ALI ${ }^{5}$ \\ 1. Assistant Professors, Professor and Chairman, Department of Agronomy, The University of Poonch Rawalakot (AJK), \\ Pakistan. aamir1801@yahoo.com; 2. Assistant Professor, Department of Agronomy, University of Agriculture Faisalabad, \\ Pakistan; 3. Assistant Professor, Department of Soil and Environmental Sciences, The University of Poonch Rawalakot (AJK), \\ Pakistan; 4. Assistant Professor, Department of Life Sciences, Islamia University Bahawalpur, Pakistan; 5. Assistant \\ Professor, Institute of Agricultural Sciences, University of Punjab, Lahore, Pakistan.
}

\begin{abstract}
Restoration, preservation and sustainability of agricultural resources including soil demands biologically and economically viable farming practices. For boosting physico-chemical properties of soil from 2012 to 2015, three legumes including cowpea, cluster bean and soybean were intercropped with sorghum in 40-60, 75-25 and 100-100 seed blending ratios, while pure stand of sorghum was kept for comparison. Correlation studies were also conducted to determine linear or inverse relationship between physiological and agronomic attributes with green forage yield of sorghum. Results revealed that intercropping systems were not effective in significantly improving the physical properties of soil, however soybean and sorghum mixed seeded crop in 100-100 seed ratio resulted in the highest total and available nitrogen especially during last two years of the study and it was followed by mixed seeded crop of cluster bean and sorghum (100-100 seed ratio), while pure stand of sorghum appeared to be the most exhaustive farming system. Correlation analysis depicted a linear relationship between all agronomic attributes (seedling count, plant population at harvest, plant height, stem diameter, number of leaves and leaf area per plant, fresh and dry weights per plant) and physiological growth parameters (leaf area index and leaf area duration, crop growth rate and net assimilation rate) with forage yield of sorghum. Thus, legumes inclusion was found to be effective in restoring soil fertility, while long term legumes inclusion by following rotation may be suggested.
\end{abstract}

KEYWORDS: Available nitrogen. Linear correlation. Mixed intercropping. Organic matter

\section{INTRODUCTION}

Soil is the most extensively used and dangerously over-exploited agricultural resource in modern intensive farming systems. Productivity based, market oriented and profit centered farming practices have taken their toll for bringing soils under plough to a precarious conditions (IQBAL et al., 2018a). Soil fertility is continuously on decline despite the use of chemical fertilizers on a wide scale. Organic farming has yet not got required support to be widely practiced for many crops owing to comparatively lesser yields (KUMAR et al., 2016; FRANCA et al., 2016). Legumes inclusion in cropping systems might lead to soil fertility buildup due to biological nitrogen fixation as well as other physico-chemical properties improvement owing to green manure addition by leaf shattering in the longer run.

Sorghum (Sorghum bicolor L.) is an excellent annual summer season fodder crop and yields much higher tonnage of green forage (YANG et al., 2016). It can be fed in green succulent form or preserved as hay and silage (IQBAL 2015). Although, sorghum produces good quality forage with exceptionally higher efficacy of applied nutrients and irrigation water but still it has been reported to be a severely exhaustive crop as far as soil fertility and its overall health are concerned (IQBAL et al., 2016). The choice of legume crop for intercropping with sorghum is a crucial factor that needs to be considered in order to get the real benefits for soil and added advantage of intercropping in terms of productivity per unit area.

Cowpea (Vigna unguiculata L.) holds potential to be intercropped with sorghum (IQBAL et al., 2018b) because of its drought and heat resisting characteristics (IQBAL 2015a). Its ability to tolerate shade is another factor which favors its intercropping with taller cereals like sorghum. Cluster bean (Cyamopsis tetragonoloba L.) is another leguminous crops having the ability to fix 
atmospheric nitrogen and helps to boost fertility status of soil. It is also shade tolerant and has the ability to grow well in nutrient-limited conditions (IQBAL 2015b). Soybean (Glycine $\max$ L.) is ranked at top slot among leguminous forage crops owing to better agro-qualitative attributes. Although, soybean remained inferior to cowpea and cluster bean as far as shade tolerance is concerned, but it's comparatively higher potential to fix atmospheric nitrogen supports its inclusion in cropping systems (KADAM; BAIG 2008). However, there is a serious lack of field investigations for determining the sort of relationship between yield components and forage yield of sorghum sown in intercropping with different legumes under varied planting geometries.

In order to fill this knowledge and research gap, four years long field trials were executed to determine the impact of sorghum-legumes intercropping systems on physical and chemical characteristics of soil. Correlation between yield components and forage yield of sorghum were also determined to propose recommendations for breeding new sorghum cultivars with improved yield attributes for boosting total biomass production.

\section{MATERIAL AND METHODS}

\section{Study area}

A field trial was executed to determine the influence of different legumes sown as mixed seeded crops with forage sorghum on physicochemical properties of soil. This field investigation was also intended to determine the type of relationship between yield attributes and forage yield of sorghum. Different locations of agronomic research farms of University of Agriculture, Faisalabad were used to carry on field trials for four subsequent years (2012-2015). $73^{\circ}$ East longitude, $31^{\circ}$ North latitude is the geographical location of our experimental site with 184 meters altitude from the sea level (IQBAL et al., 2017).

\section{Crop husbandry}

Cowpea (cv. P-518), cluster bean (cv. BR99) and soybean (cv. Ajmeri) were intercropped with sorghum (cv. Hegari) during summer months of 2012,2013, 2014 and 2015. The sowing was done by using single row cotton drill in $30 \mathrm{~cm}$ spaced rows. The intercropping systems included IS $_{1}$ (cowpea-sorghum in 40-60 mixed seeding ratio), $\mathrm{IS}_{2}$ (cowpea-sorghum in 75-25 mixed seeding ratio), $\mathrm{IS}_{3}$ (cowpea-sorghum in 100-100 mixed seeding ratio), $\mathrm{IS}_{4}$ (cluster bean-sorghum 40-60 mixed seeding ratio), $\mathrm{IS}_{5}$ (cluster bean-sorghum 75-25 mixed seeding ratio), $\mathrm{IS}_{6}$ (cluster bean-sorghum in 100-100 mixed seeding ratio), $\mathrm{IS}_{7}$ (soybean-sorghum in 40-60 mixed seeding ratio), IS $_{8}$ (soybeansorghum in 75-25 mixed seeding ratio), $\mathrm{IS}_{9}$ (soybean-sorghum in 100-100 mixed seeding ratio), $\mathrm{IS}_{10}$ (pure stand of sorghum). Randomized complete block design with regular arrangement was used to execute the trial. The net plot size was maintained at $6 \mathrm{~m} \times 9 \mathrm{~m}$. The agronomic management plan was kept same and uniform for all intercropping systems, while no additional inputs were applied for legume intercrops. The meteorological data for crop growing seasons during 2012-2015 are illustrated in Table 1, which were recorded from the meteorological observation center located in the close vicinity of experimental site.

\section{Physico-chemical analyses of soil}

Soil samples were collected from a depth of 30,45 and $60 \mathrm{~cm}$ with the help of hand auger and were mixed thoroughly to make homogenized representative samples which were then oven dried at $70^{\circ} \mathrm{C}$, crushed, sieved in $250 \mu \mathrm{m}$ and preserved in zipped-locked bags. The soil samples were preserved in three replicates for each treatment. $\mathrm{pH}$ meter was used to measure the $\mathrm{pH}$ of soil (ADDIS et al., 2016), while conductivity meter was used for determining the electrical conductivity (EC) (SPARKS et al., 1996). The estimation of soil organic carbon was done by following the procedures suggested by Walkley and Black involving rapid titration method (KACHI et al., 2016). The organic matter was estimated by Bemlen method (NARESH et al., 2014). Total nitrogen was calculated by performing distillation in Kjeldahl's apparatus and subsequently titration with concentrated $\mathrm{H}_{2} \mathrm{SO}_{4}$ was performed. Phosphorous was determined by using Olsen's method (YOUNIS et al., 2010), while potassium was calculated by following the standard procedure as outlined by AOAC (2003). 
Table 1. Agro-meteorological data of experimental site during crop growing seasons of four consecutive years

\begin{tabular}{|c|c|c|c|c|c|c|c|c|c|c|c|c|c|c|c|}
\hline \multirow[t]{2}{*}{ Months } & \multicolumn{5}{|c|}{ Temperature $\left({ }^{\circ} \mathrm{C}\right)$} & \multicolumn{5}{|c|}{ Precipitation (mm) } & \multicolumn{5}{|c|}{ Relative humidity (\%) } \\
\hline & 2012 & 2013 & 2014 & 2015 & 10YA & 2012 & 2013 & 2014 & 2015 & $10 Y A$ & 2012 & 2013 & 2014 & 2015 & $10 \mathrm{YA}$ \\
\hline June & 41.0 & 40.3 & 41.5 & 42.1 & 40.1 & 39 & 41 & 43 & 37 & 39 & 57 & 62 & 64 & 61 & 62 \\
\hline July & 38.0 & 39.5 & 38.6 & 41.5 & 41.0 & 91 & 101 & 105 & 98 & 102 & 67 & 64 & 71 & 65 & 64 \\
\hline August & 36.3 & 37.1 & 37.8 & 39.3 & 36.9 & 72 & 66 & 79 & 63 & 71 & 61 & 54 & 65 & 58 & 60 \\
\hline Total/Mean & 38.4 & 38.9 & 39.3 & 40.9 & 39.2 & 202 & 208 & 227 & 198 & 212 & 61.6 & 60.0 & 66.6 & 61.3 & 62.0 \\
\hline
\end{tabular}

10YA: 10 years average 


\section{Yield and yield attributes correlation studies}

For correlation studies, yield attributes of forage sorghum were estimated at the time of harvesting. Plant height of ten randomly selected plants from interior rows was determined using measuring tape from base of the plant to the tip of highest leaf of plant. Stem diameter was estimated with the help of vernier caliper from three points of plant including base, middle and top portions and then their average was taken. Ten randomly selected plants were taken and their leaves were removed and weighed. Then a sub sample of $10 \mathrm{~g}$ was kept over the screen of leaf area meter (Licor model3100 ) to record leaf area. Later on, this leaf area was used for calculating leaf area per plant.

Leaf area index (LAI), leaf area duration (LAD), crop growth rate (CGR) and net assimilation rate (NAR) were calculated by using procedures suggested by HUNT (1978).

LAI $=$ Leaf area $\left(\mathrm{m}^{2}\right) /$ Land area $\left(\mathrm{m}^{2}\right) \ldots$ (1)

$\mathrm{LAD}=\left(\mathrm{LAI}_{1}+\mathrm{LAI}_{2}\right)\left(\mathrm{t}_{2}-\mathrm{t}_{1}\right) / 2$

Where

$\mathrm{LAI}_{1}=$ Leaf area index taken at first harvest

$\mathrm{LAI}_{2}=$ Leaf area index taken at second harvest

$\mathrm{t}_{1}=$ Date of measuring first leaf area index

$\mathrm{t}_{2}=$ Date of measuring second leaf area index

$\mathrm{CGR}=\left(\mathrm{W}_{2}-\mathrm{W}_{1}\right) /\left(\mathrm{t}_{2}-\mathrm{t}_{1}\right)$.

Where, $\mathrm{W}_{1}$ and $\mathrm{W}_{2}$ are the dry weight at harvesting times of $t_{1}$ and $t_{2}$ respectively.

$\mathrm{NAR}=\mathrm{TDM} / \mathrm{LAD}$

Where, TDM and LAD are the total dry matter yield and leaf area duration, respectively.

\section{Statistical analysis}

The recorded data of physico-chemical properties of the soil were subjected to analysis of variance technique with the help of a computer run statistical program "Statistix 8.1 version" and LSD test at $5 \%$ probability level was set to separate treatment means by using the same statistical program. For correlation studies, recorded data were subjected to correlation analysis by using Microsoft's Excel program in order to establish the nature of relation between physiological and yield attributes with forage yield of sorghum.

\section{RESULTS AND DISCUSSION}

\section{Effect of sorghum-legumes intercropping systems on soil quality}

The impact of sorghum and legumes intercropping systems on physical properties of soil including $\mathrm{pH}, \mathrm{EC}$, organic matter and organic carbon was studied as depicted in Table 2.

\section{Soil pH and electrical conductivity}

The statistical analysis of recorded data revealed that soybean sown with sorghum especially as mixed seeded crop of soybean-sorghum in 100100 seed blending ( $\mathrm{IS}_{9}$ ) improved soil physical characteristics despite the fact that it was not statistically significant with respect to other sorghum-legumes intercropping systems (Table 2). During fourth year of study, soybean-sorghum mixed seeded crop slightly reduced soil $\mathrm{pH}$ (7.76), while cluster bean boosted soil organic matter minutely $(0.79 \%)$. Solo Sorghum ( IS $\left._{10}\right)$ negatively affected all physical properties of soil except EC, while no significant variations were observed with respect to other intercropping systems (Table 2). It could be inferred that although minute improvement in soil physical properties occurred but there was no statistically significant difference among treatments which illustrated the fact that comparatively longer period of time was required to bring significant improvement in the physical properties of soil under leguminous crops. These results corroborate with the findings of Kumar et al. (2016), who reported that it is not possible to amend soil physical properties with organic amendments in short term and only long term strategies could yield some positive results as far as physical properties of the soil were concerned. Any such improvement brought with organic means could be more sustainable, economical and eco-cum-farmerfriendly in comparison with chemical amendments.

\section{Organic matter and carbon}

Organic carbon is a major constituent of soil organic matter. Legumes inclusion as an intercrops with forage sorghum had no significant effect on organic carbon and organic matter of the soil over the years as organic carbon was found to be in the range of 0.31 to $0.39 \%$, while that of organic matter was $0.61-0.72 \%$ (Table 2). These finding are in line with the conclusions made by Kumar et al. (2016), who reported that soil organic matter was not affected by crops, be it cereals or legumes in short term and planting geometry of component crops had really nothing to do with the organic matter of the soil. Furthermore, prior research findings of Naresh et al. (2014) suggested that legumes intercropping as green manuring crop might be helpful in boosting the soil organic matter and that too in long run, while different legumes might be included as intercrops by following the principle of crop rotation. 


\section{Total and available nitrogen}

Chemical properties of the soil were significantly affected by sorghum-legumes binary mixtures. First two years of the study did not witness any noticeable buildup of total nitrogen in soil, an appreciable improvement was recorded during last years. Soybean sown as blended crop with sorghum $\left(\mathrm{IS}_{9}\right)$ recorded the highest total nitrogen $(0.074$ and $0.079 \%$ in 2014 and 2015 respectively) which declined to 0.050 and $0.048 \%$ in 2014 and 2015 respectively where forage sorghum was grown in pure stand ( IS $_{10}$ ) (Table 3 ). Mixed seeded crop of cowpea-sorghum (IS ${ }_{3}$ ) remained superior to mixed seeded crop of cluster bean and sorghum $\left(\mathrm{IS}_{6}\right)$. Similarly during last three years of study, a significant change in nitrogen availability was recorded as $\mathrm{IS}_{9}$ again recorded the highest values of available nitrogen (7.2, 7.9 and $8.2 \mathrm{ppm}$ in 2013, 2014 and 2015 respectively), which was followed by $\mathrm{IS}_{7}$ which in turn was followed by $\mathrm{IS}_{3}$. $\mathrm{IS}_{10}$ was the most exhaustive farming system with the minimum available nitrogen during all years of study (Table 3). Legumes especially soybean fixed nitrogen in greater quantities than cowpea and cluster bean which saved nitrogen over the years and ultimately legumes inclusion was recorded to be a soil nitrogen building factor, while sorghum only relied on soil solution for nitrogen uptake and ultimately it led to a significant decline in total and available nitrogen (SHAHI et al., 2016; YAN et al., 2016).

\section{Available phosphorous and potassium}

No significant variation was observed among sorghum-legumes intercropping systems sown in varied mixed seeding ratios over the years as far as available phosphorous and potassium are concerned. The ranges of available phosphorous and potassium were 0.91-1.02 ppm and 110-139 ppm from 2012 to 2015 (Table 3). These results are in line with those of Kitonyo et al. (2013), who concluded that legumes inclusion as intercrops was an effective strategy for increasing phosphorous and potassium availability in short term and suggested that organic sources of nutrients instead of chemical fertilizers might lead to sustainable buildup phosphorous and potassium in the soil.

\section{Correlation studies}

\section{Seedling count and plant population at harvest}

Correlation analysis revealed that there was a linear relationship between seedling count and plant population at harvest with green forage yield of sorghum. Seedling density of $68 \mathrm{~m}^{-2}$ led to green forage yield of $43.9 \mathrm{t} \mathrm{ha}^{-1}$ which was reduced to 32.1 $\mathrm{t} \mathrm{ha}^{-1}$ when seedling count was declined to $52.0 \mathrm{~m}^{-2}$ as depicted in Figure 1. Thus, it is of utmost importance to maintain optimal seedling count by keeping strict vigilance on seed germination for obtaining appropriate green forage yield (IQBAL et al., 2016). Similarly, plant population at harvest of $66 \mathrm{~m}^{-2}$ resulted in the highest green forage yield, while $49 \mathrm{~m}^{-2}$ led to significantly lower forage yield (Figure 1). Plant population of sorghum at harvest needs to be maintained while not allowing too much plants going out of competition to ensure higher efficacy of farm applied resources as sub-optimal plant population results in wastage of precious resources especially irrigation water and fertilizers (TAKIM 2012; KADAM; BAIG 2008).

\section{Plant height and stem diameter}

The experimental plots where comparatively taller sorghum plants $(311.7 \mathrm{~cm})$ with higher stem diameter $(3.8 \mathrm{~cm})$ were recorded, forage yield was also maximized while plant height of $260.0 \mathrm{~cm}$ with stem diameter of $2.7 \mathrm{~cm}$ led to the lowest biomass production (Figure 1). Mehdi (2013) and Moo (2005) suggested that sorghum and maize remained stunted in intercropping with legumes which led to significant reduction in their yield. Similarly, Oseni and Aliyu (2010) also suggested that lower stem diameter of sorghum in intercropping with cowpea gave significantly less forage yield because stem was the most bulky plant part and contributed a lion's share in total biomass production.

\section{Number of leaves and leaf area per plant}

Significantly higher number of leaves (13.7) resulted in the highest leaf area per plant (2299.1 $\mathrm{cm}^{2}$ ) which ultimately recorded the maximum green forage yield, while the lowest green forage yield was recorded in plots where there were minimum number of leaves (10.8) as well as leaf area per plant $\left(2183.8 \mathrm{~cm}^{2}\right)$ (Figure 2). The higher number of leaves resulted in higher leaf area per plant which was the crucial factor in boosting the photosynthetic efficacy of cereal forages including sorghum. Zhang and $\mathrm{Li} \mathrm{(2003)} \mathrm{concluded} \mathrm{that} \mathrm{intercropping} \mathrm{resulted}$ in lowering the forage yield of cereals owing to poor performance in terms of agronomic traits like leaf area per plant. 
Table 2. Physical properties of soil in sorghum-legumes intercropping systems

\begin{tabular}{|c|c|c|c|c|c|c|c|c|c|c|c|c|c|c|c|c|}
\hline \multirow[t]{2}{*}{ Treatments } & \multicolumn{4}{|c|}{ Organic matter $(\%)$} & \multicolumn{4}{|c|}{ Organic carbon $(\%)$} & \multicolumn{4}{|c|}{$\mathrm{EC}\left(\mathrm{dS} \mathrm{m} \mathrm{m}^{-1}\right)$} & \multicolumn{4}{|l|}{$\mathrm{pH}$} \\
\hline & 2012 & 2013 & 2014 & 2015 & 2012 & 2013 & 2014 & 2015 & 2012 & 2013 & 2014 & 2015 & 2012 & 2013 & 2014 & 2015 \\
\hline $\mathrm{IS}_{1}$ & 0.61 & 0.64 & 0.62 & 0.63 & 0.31 & 0.33 & 0.36 & 0.35 & 1.64 & 1.62 & 1.61 & 1.61 & 7.87 & 7.85 & 7.86 & 7.84 \\
\hline $\mathrm{IS}_{2}$ & 0.63 & 0.61 & 0.64 & 0.61 & 0.34 & 0.31 & 0.33 & 0.34 & 1.62 & 1.64 & 1.65 & 1.59 & 7.89 & 7.88 & 7.86 & 7.82 \\
\hline $\mathrm{IS}_{3}$ & 0.67 & 0.70 & 0.72 & 0.70 & 0.32 & 0.35 & 0.34 & 0.37 & 1.66 & 1.63 & 1.64 & 1.58 & 7.86 & 7.84 & 7.82 & 7.80 \\
\hline $\mathrm{IS}_{4}$ & 0.65 & 0.66 & 0.64 & 0.71 & 0.37 & 0.34 & 0.35 & 0.38 & 1.63 & 1.66 & 1.62 & 1.61 & 7.88 & 7.87 & 7.85 & 7.86 \\
\hline $\mathrm{IS}_{5}$ & 0.60 & 0.66 & 0.65 & 0.69 & 0.35 & 0.38 & 0.37 & 0.39 & 1.62 & 1.61 & 1.62 & 1.62 & 7.85 & 7.83 & 7.84 & 7.82 \\
\hline $\mathrm{IS}_{6}$ & 0.66 & 0.73 & 0.77 & 0.79 & 0.33 & 0.31 & 0.33 & 0.36 & 1.67 & 1.65 & 1.64 & 1.61 & 7.84 & 7.81 & 7.80 & 7.83 \\
\hline $\mathrm{IS}_{7}$ & 0.64 & 0.62 & 0.65 & 0.63 & 0.36 & 0.33 & 0.37 & 0.38 & 1.64 & 1.67 & 1.63 & 1.63 & 7.92 & 7.88 & 7.86 & 7.83 \\
\hline $\mathrm{IS}_{8}$ & 0.68 & 0.65 & 0.70 & 0.67 & 0.32 & 0.35 & 0.36 & 0.35 & 1.66 & 1.65 & 1.64 & 1.61 & 7.86 & 7.87 & 7.89 & $7 . .85$ \\
\hline $\mathrm{IS}_{9}$ & 0.71 & 0.68 & 0.72 & 0.69 & 0.37 & 0.38 & 0.35 & 0.41 & 1.63 & 1.65 & 1.66 & 1.59 & 7.81 & 7.80 & 7.78 & 7.76 \\
\hline $\mathrm{IS}_{10}$ & 0.58 & 0.55 & 0.54 & 0.55 & 0.38 & 0.36 & 0.32 & 0.34 & 1.61 & 1.62 & 1.64 & 1.60 & 7.91 & 7.88 & 7.89 & 7.87 \\
\hline LSD 0.05 & N.S. & N.S. & N.S. & N.S. & N.S. & N.S. & N.S. & N.S. & N.S. & N.S. & N.S. & N.S. & N.S. & N.S. & N.S. & N.S. \\
\hline
\end{tabular}

Table 3. Chemical properties of soil in sorghum-legumes intercropping systems $(\mathrm{p}<0.05)$

\begin{tabular}{|c|c|c|c|c|c|c|c|c|c|c|c|c|c|c|c|c|}
\hline \multirow[t]{2}{*}{ Treatments } & \multicolumn{4}{|c|}{ Total nitrogen $(\%)$} & \multicolumn{4}{|c|}{ Available nitrogen (ppm) } & \multicolumn{4}{|c|}{ Available phosphorous (ppm) } & \multicolumn{4}{|c|}{ Available potassium (ppm) } \\
\hline & 2012 & 2013 & 2014 & 2015 & 2012 & 2013 & 2014 & 2015 & 2012 & 2013 & 2014 & 2015 & 2012 & 2013 & 2014 & 2015 \\
\hline $\mathrm{IS}_{1}$ & 0.056 & 0.057 & $0.058^{\mathrm{d}}$ & $0.062^{\mathrm{c}}$ & 6.3 & $6.5^{\mathrm{d}}$ & $6.9^{\mathrm{c}}$ & $7.0^{\mathrm{c}}$ & 1.01 & 0.94 & 0.97 & 0.95 & 113 & 114 & 119 & 126 \\
\hline $\mathrm{IS}_{2}$ & 0.055 & 0.054 & $0.060^{\mathrm{d}}$ & $0.065^{\mathrm{c}}$ & 6.1 & $6.3^{\mathrm{e}}$ & $6.3^{\mathrm{d}}$ & $6.8^{\mathrm{c}}$ & 0.94 & 0.96 & 0.94 & 0.91 & 111 & 113 & 116 & 122 \\
\hline $\mathrm{IS}_{3}$ & 0.059 & 0.065 & $0.069^{\mathrm{b}}$ & $0.075^{\mathrm{b}}$ & 6.5 & $6.9^{\mathrm{b}}$ & $7.4^{\mathrm{b}}$ & $7.7^{\mathrm{b}}$ & 0.95 & 0.99 & 0.91 & 0.96 & 117 & 119 & 125 & 134 \\
\hline $\mathrm{IS}_{4}$ & 0.053 & 0.054 & $0.058^{\mathrm{d}}$ & $0.064^{\mathrm{c}}$ & 6.2 & $6.2^{\mathrm{e}}$ & $6.5^{\mathrm{d}}$ & $6.6^{\mathrm{c}}$ & 0.97 & 0.92 & 0.96 & 1.0 & 113 & 116 & 118 & 119 \\
\hline $\mathrm{IS}_{5}$ & 0.054 & 0.056 & $0.057^{\mathrm{d}}$ & $0.062^{\mathrm{c}}$ & 6.0 & $6.3^{\mathrm{e}}$ & $6.7^{\mathrm{cd}}$ & $6.9^{c}$ & 0.99 & 1.03 & 0.97 & 0.90 & 111 & 110 & 113 & 115 \\
\hline $\mathrm{IS}_{6}$ & 0.057 & 0.062 & $0.066^{\mathrm{c}}$ & $0.073^{b}$ & 6.3 & $6.6^{\mathrm{c}}$ & $7.0^{\mathrm{c}}$ & $7.4^{\mathrm{bc}}$ & 0.93 & 0.95 & 0.98 & 1.01 & 114 & 116 & 120 & 128 \\
\hline $\mathrm{IS}_{7}$ & 0.058 & 0.060 & $0.069^{b}$ & $0.073^{b}$ & 6.6 & $6.9^{\mathrm{b}}$ & $7.0^{\mathrm{c}}$ & $7.6^{\mathrm{b}}$ & 0.96 & 1.02 & 0.99 & 1.00 & 116 & 119 & 123 & 130 \\
\hline $\mathrm{IS}_{8}$ & 0.060 & 0.066 & $0.067^{\mathrm{bc}}$ & $0.071^{\mathrm{b}}$ & 6.5 & $6.7^{\mathrm{c}}$ & $6.9^{c}$ & $7.3^{\mathrm{bc}}$ & 0.92 & 0.99 & 0.95 & 0.96 & 114 & 117 & 120 & 129 \\
\hline $\mathrm{IS}_{9}$ & 0.066 & 0.070 & $0.074^{\mathrm{a}}$ & $0.079^{\mathrm{a}}$ & 6.8 & $7.2^{\mathrm{a}}$ & $7.9^{\mathrm{a}}$ & $8.2^{\mathrm{a}}$ & 0.98 & 1.01 & 0.92 & 0.97 & 118 & 121 & 129 & 139 \\
\hline $\mathrm{IS}_{10}$ & 0.052 & 0.050 & $0.050^{\mathrm{e}}$ & $0.048^{\mathrm{d}}$ & 6.0 & $5.9^{\mathrm{f}}$ & $6.0^{\mathrm{e}}$ & $5.8^{\mathrm{d}}$ & 1.00 & 0.98 & 0.96 & 0.99 & 110 & 108 & 109 & 111 \\
\hline LSD 0.05 & N.S. & N.S. & 0.04 & 0.03 & N.S. & 0.2 & 0.4 & 0.5 & N.S. & N.S. & N.S. & N.S. & N.S. & N.S. & N.S. & N.S. \\
\hline
\end{tabular}



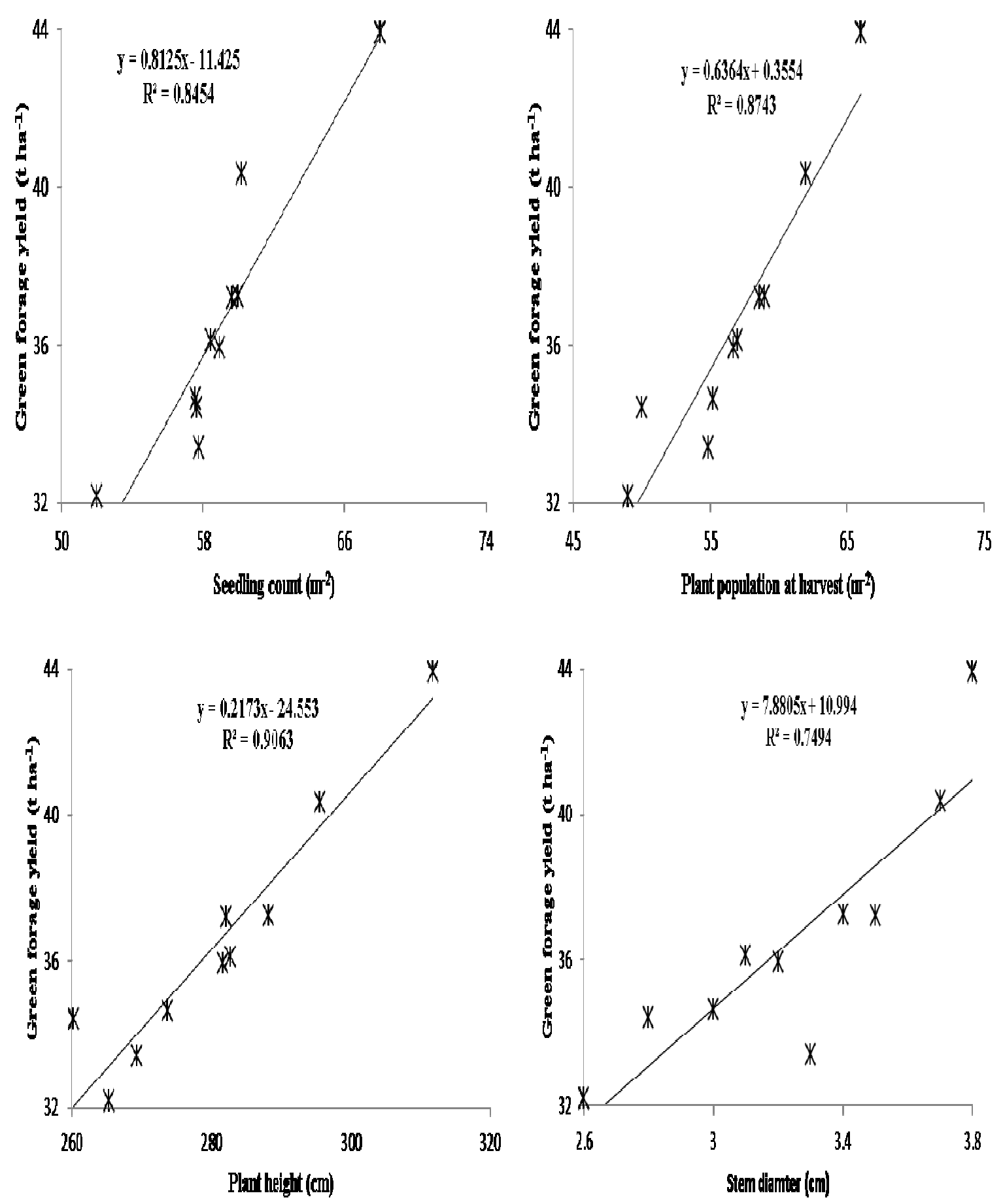

Figure 1. Correlation analysis for plant height, stem diameter, number of leaves and leaf area per plant and forage yield of sorghum (4-years pooled data and combined analysis)

\section{Fresh and dry weights per plant}

Fresh and dry weights per plant had direct relationship with green forage yield and dry matter yield respectively. Fresh and dry weights per plant with highest values of $217.1 \mathrm{~g}$ and $66.8 \mathrm{~g}$ respectively led to the highest green forage yield and dry matter biomass of sorghum, while only $13 \%$ and $18 \%$ reduction in fresh and dry weights per plant resulted in $24 \%$ and $29 \%$ reduction of green forage yield and dry matter biomass of sorghum (Figure 2). Fresh and dry weights per plant were reported to be the reliable parameters to estimate green forage yield and dry biomass production of cereal forages for having direct relationship (KUMAR et al., 2005). 


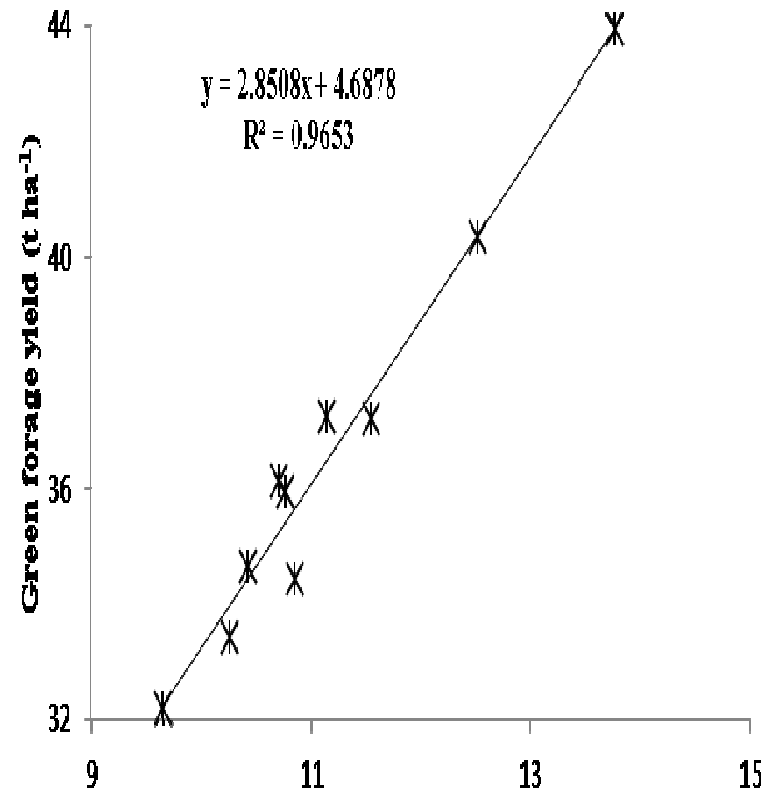

Nhmber oflearesper plant

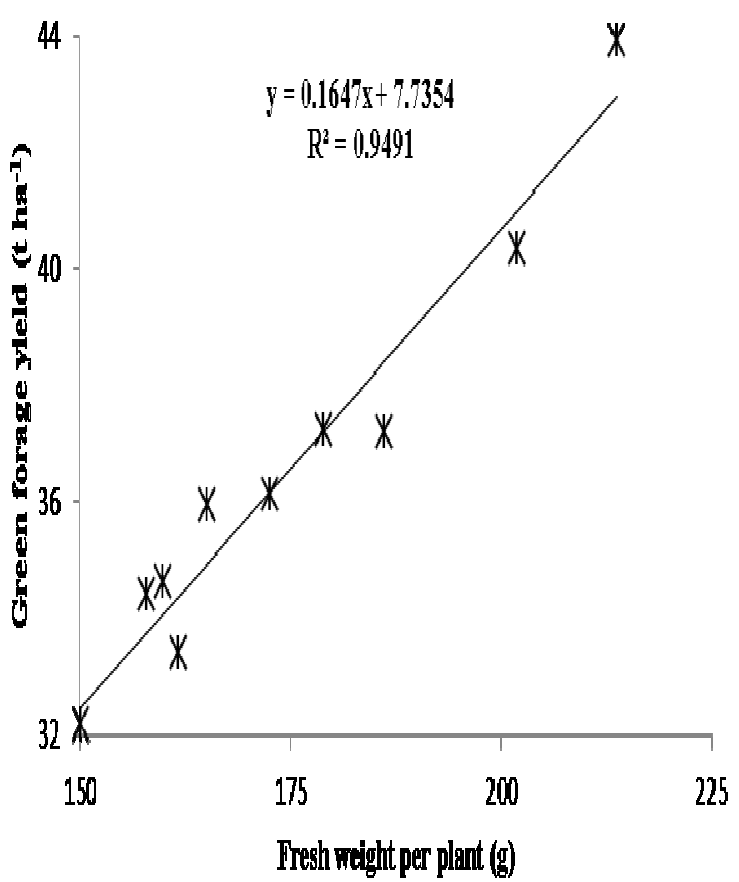

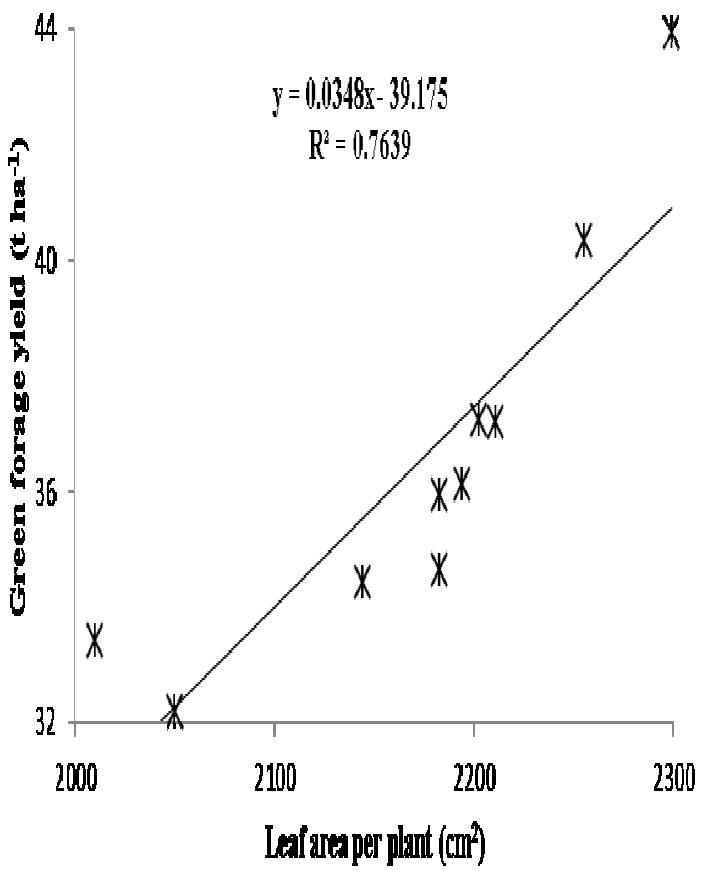

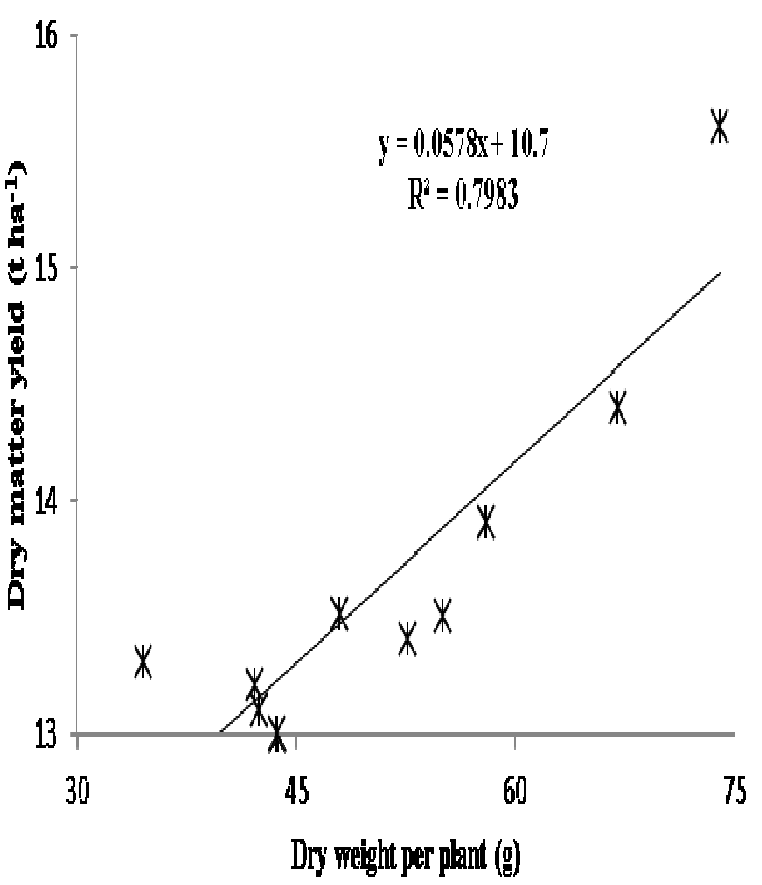

Figure 2. Correlation analysis for number of leaves and leaf area per plant, fresh and dry weights per plant and forage yield of sorghum (4-years pooled data and combined analysis)

Leaf area index, leaf area duration, crop growth rate and net assimilation rate

All physiological growth parameters of sorghum were also recorded to have linear relationship with green forage yield. The highest green forage yield was recorded where there was maximum leaf area index (5.9) and leaf area duration (72.7 days), but when leaf area index and leaf area duration were reduced to 5.0 and 61.2 days respectively, the lowest productivity of sorghum was obtained (Figure 3). The maximum values of crop growth rate $\left(48.1 \mathrm{~g} \mathrm{~m}^{-2}\right.$ day $\left.^{-1}\right)$ and net assimilation rate $\left(21.9 \mathrm{~g} \mathrm{~m}^{-2} \mathrm{day}^{-1}\right)$ resulted in the highest green forage yield of sorghum, while crop growth rate of $35.6 \mathrm{~g} \mathrm{~m}^{-2} \mathrm{day}^{-1}$ and net assimilation rate of $18.7 \mathrm{~g} \mathrm{~m}^{-2}$ day $^{-1}$ recorded the lowest green forage yield and thus establishing a linear correlation. Earlier research findings of Jokinen 
(1991) and Kitonyo et al. (2013) also support our results who reported that better physiological growth led to higher productivity of cereal forages and concluded that higher leaf area triggered the photosynthetic process which resulted in higher biomass accumulation over time.
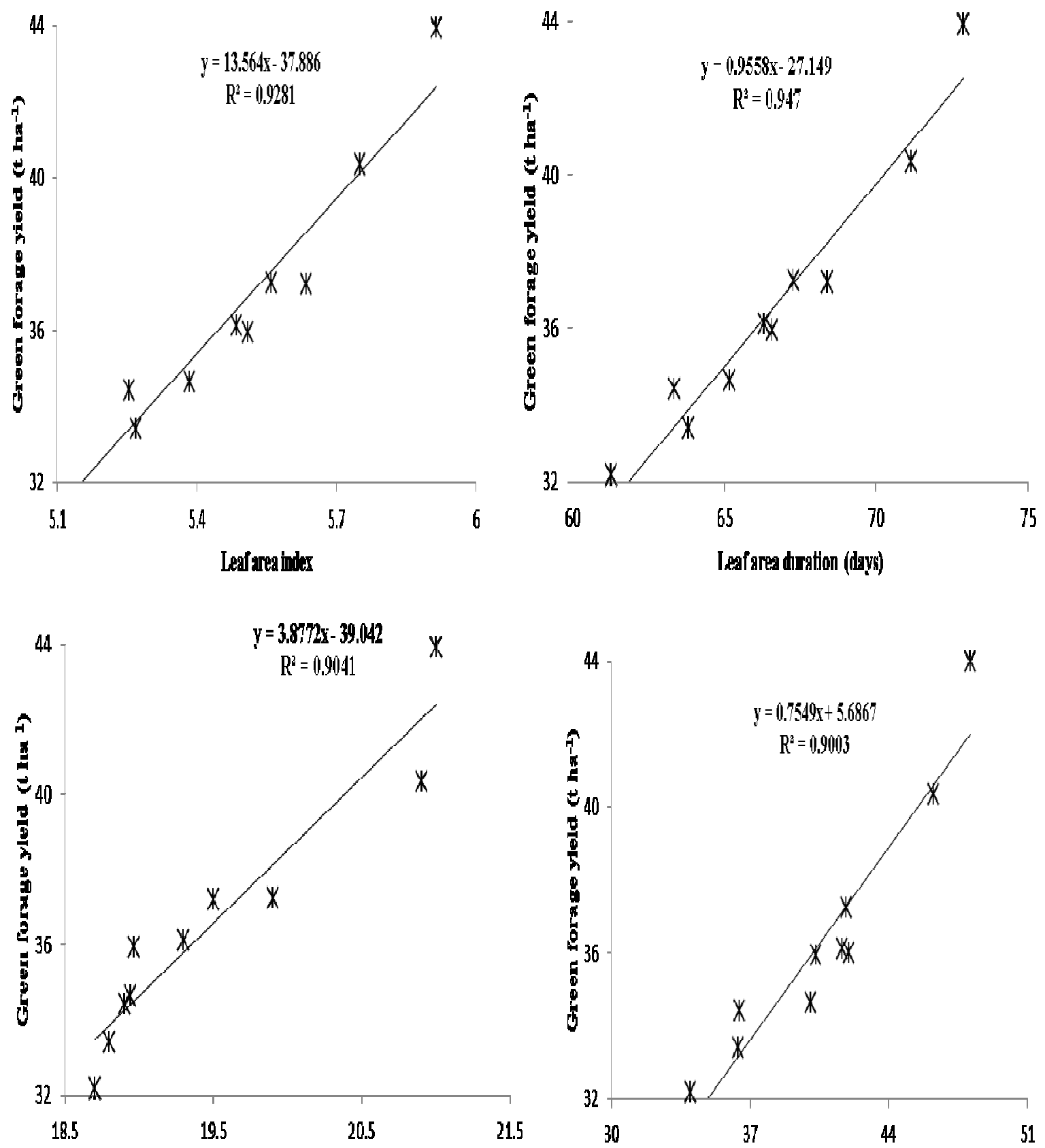

Vet assimilation rate (g $\mathrm{m}^{2} \mathrm{day}$ )

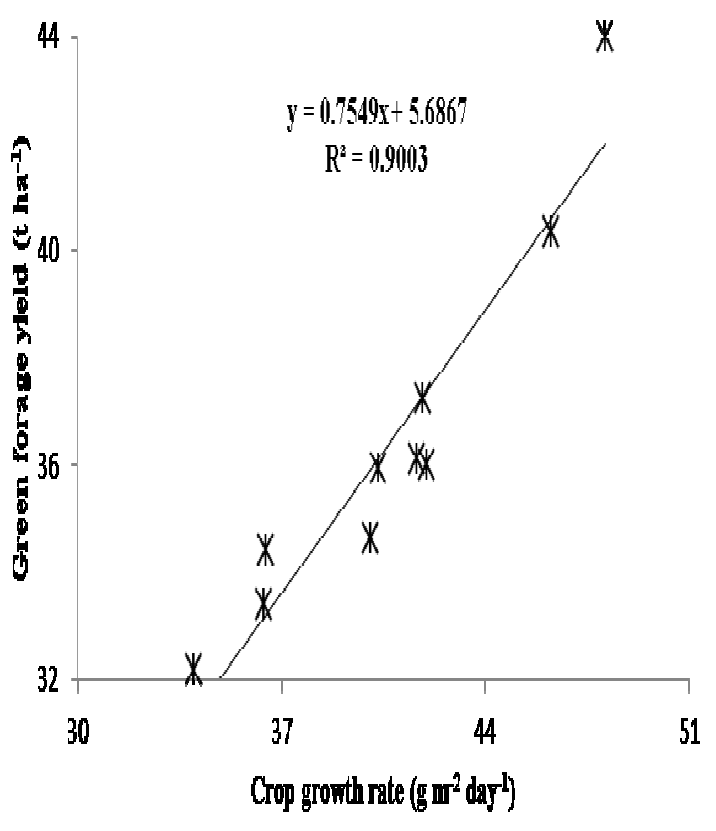

Figure 3. Correlation analysis for leaf area index, leaf area duration, crop growth rate, net assimilation rate and forage yield of sorghum (4-years pooled data and combined analysis)

\section{CONCLUSIONS}

Legumes inclusion as an intercrops with forage sorghum was not effective in improving physical characteristics of the soil in short run.
Chemical properties of soil especially total nitrogen and available nitrogen were boosted up in the last two years of investigation which depicted that inclusion of legume was effective in restoring soil fertility and might be investigated further to 
develop it as a biological tool for soil conservation in the long run.

Correlation studies revealed that all agronomic and physiological growth parameters under study were linearly correlated with green forage yield of sorghum thus opening broad horizons of plant breeding to develop new cultivars with higher potential for plant height and stem diameter along with greater leaf area. It would help to bridge the gap of forage supply and demand for ensuring food security of populace across the globe by increasing milk and meat production.
These results may serve as a reference point for other researchers to conduct similar research for other forage crops and plant breeders to strive for developing sorghum cultivars with higher potential for green forage yield.

\section{ACKNOWLEDGEMENTS}

Thanks to the Higher Education Commission of Pakistan for providing Indigenous Fellowship to the principal author (5000Fellowships-2AV1-215).

RESUMO: A restauração, a preservação e a sustentabilidade dos recursos agrícolas, incluindo o solo, exigem práticas agrícolas biologicamente e economicamente viáveis. Para aumentar as propriedades físico-químicas do solo de 2012 a 2015, três leguminosas, incluindo feijão-fradinho, guar e soja, foram consorciadas com sorgo nas proporções de mistura de 40-60, 75-25 e 100-100, enquanto que o sorgo puro foi mantido por comparação. Estudos de correlação também foram conduzidos para determinar a relação linear ou inversa entre atributos fisiológicos e agronômicos com a produtividade de forragem verde do sorgo. Os resultados revelaram que os sistemas consorciados não foram eficazes em afetar significativamente as propriedades físicas do solo, no entanto, soja e sorgo misturados na proporção de sementes 100-100 resultou no maior nitrogênio total e nitrogênio disponível, especialmente durante os últimos dois anos do estudo e foi seguido do plantio de sementes mistas de guar e sorgo (100-100 rácio de semente), enquanto a monocultura de sorgo parecia ser o sistema de agricultura mais exaustivo. A análise de regressão mostrou uma correlação linear entre todos os atributos agronômicos (contagem de plântulas, população de plantas na colheita, altura de planta, diâmetro de caule, número de folhas e área foliar por planta, peso fresco e seco por planta) e parâmetros de crescimento fisiológico (índice de área foliar e duração da área foliar, taxa de crescimento da cultura e taxa de assimilação líquida) com o rendimento de forragem do sorgo. Assim, a inclusão de leguminosas foi eficaz no aumento da fertilidade do solo, enquanto a inclusão de leguminosas a longo prazo por rotação de diferentes leguminosas é sugerida.

PALAVRAS-CHAVE: Nitrogênio disponível. Correlação linear. Consórcio misto. Matéria orgânica.

\section{REFERENCES}

ADDIS, H.; ANDREAS, K.; THEIB, O.; STEFAN, S. Linking selected soil properties to land use and hill slope- A watershed case study in the Ethiopian highlands. Soil \& Water Research, v. 11, p. 163-171, 2016. https://doi.org/10.17221/117/2015-SWR

AOAC-Official Methods of Analysis. 2003. 17th Edition. Association of Official Analytical Chemists. Inc. Arlington, Virginia, USA.

FRANCA, F. C. T.; SILVA, E. C.; PEDROSA, M. W.; CARLOS, L. A.;MACIEL, G. M. Tomato yield and quality under various combinations of organic compost. Bioscience Journal, v. 32, p. 1147-1154, 2016. https://doi.org/10.14393/BJ-v32n5a2016-33057

HUNT, R. Plant growth analysis. 2nd Ed. Edward Arnold, UK, 1978.

IQBAL, M. A.; IQBAL, A.; RANA, N. A. Spatio-temporal reconciliation to lessen losses in yield and quality of forage soybean (Glycine max L.) in soybean-sorghum intercropping systems. Bragantia, v. 77, 2018 a. http://dx.doi.org/10.1590/1678-4499.2017043

IQBAL, M. A.; MUZAMMIL, H. S.; SHER, A.; ZAHOOR, A.; QAISER, M.; RANA, D. K. Forage productivity of cowpea [Vigna unguiculata (L.) Walp] cultivars improves by optimization of spatial arrangements. Revista Mexicana de Ciencias Pecuarias, v. 9, p. 203-219, 2018 b.

http://dx.doi.org/10.22319/rmcp.v9i2.4335 
IQBAL, M. A.; BRANDON, J. B.; ASIF, I.; RANA, N. A.; ZUBAIR, A.; HAROON, Z. K.; BILAL, A. Agrobotanical response of forage sorghum-soybean intercropping systems under atypical spatio-temporal pattern. Pakistan Journal of Botany, v. 49, p. 987-994, 2017.

IQBAL, M. A.; IQBAL, A.; AYUB, M.; AKHTAR, J. Comparative study on temporal and spatial complementarity and profitability of forage sorghum-soybean intercropping systems. Custos e Agronegocio on line, v. 14, p. 2-18, 2016.

IQBAL, M. A. Agronomic management strategies elevate forage sorghum yield: A Review. Journal of Advanced Botany \& Zoology, v. 3, p. 1-6, 2015.

IQBAL, M. A. Improving germination and seedling vigour of cowpea (Vigna unguiculata L.) with different priming techniques. American-Eurasian Journal Agricultural \& Environmental Sciences, v. 15, p. 265$270,2015 \mathrm{a}$.

IQBAL, M. A. Cluster bean (Cyamopsis tetragonoloba L.) germination and seedling growth as influenced by seed invigoration techniques. American-Eurasian Journal Agricultural \& Environmental Sciences, v. 15, p. 197-204, 2015b.

JOKINEN, K. Yield and competition in barley variety mixtures. Journal of Agricultural Science in Finland, v. 63, p. 287-305, 1991.

KACHI, N.; SLIMANE K.; HOURIA, B. Effects of irrigated agriculture on water and soil quality (case perimeter Guelma, Algeria). Soil \& Water Research, v. 11, p. 97-104, 2016. https://doi.org/10.17221/81/2015SWR

KADAM, G. L.; BAIG, I. A. B. Studies on different planting patterns of sorghum + soybean intercropping system. International Journal of Agriculture Sciences, v. 4, p. 181-187, 2008.

KITONYO, O. M.; CHEMININGWA; MUTHOMI, J. W. Productivity of farmer-preferred maize varieties intercropped with beans in semi-arid Kenya. International Journal of Agronomy and Agricultural Research, v. 3, p. 6-16, 2013.

KUMAR, S.; VERMA, K. K.; DIWEVEDI, A.; KUMAR, V.; SINGH, A.; KUMAR, A.; BANKOTI, P. Effect of sources and methods of phosphorous application on performance, production potential and use efficiency of phosphorous in rice and physico-chemical properties of soil. Green Farming, v. 7, p. 327-331, 2016.

KUMAR, S.; RAWAT, C. R.; MELKANIA, N. P. Forage production potential and economics of maize (Zea mays) and cowpea (Vigna unguiculata) inter cropping under rainfed conditions. Indian Journal of Agronomy, v. 50, p. 184-186, 2005.

MEHDI, D. Intercropping two varieties of maize (Zea mays L.) and peanut (Arachis hypogaea L.): Biomass yield and Intercropping Advantages. International Journal of Agriculture and Forestry, v. 2, p. 11-19, 2013.

MOO, S. L. Effect of inter-cropping on the growth characteristics, yield and palatability of sorghum $\mathrm{x}$ sudangrass hybrid in 1st, 2nd and 3rd cutting time. Journal of the Korean Society of Grassland and Forage Science, v. 25, p. 23-32, 2005. https://doi.org/10.5333/KGFS.2005.25.1.023

NARESH, R. K.; TOMAR, S. S.; KUMAR, D.; SAMSHER, P.; SINGH, S.; DWIVEDI, P.; KUMAR, A. Experiences with rice grown on permanent raised beds: effect of crop establishment techniques on water use, productivity, profitability and soil physical properties. Rice Science, v. 21, p. 170-180, 2014. https://doi.org/10.1016/S1672-6308(13)60185-7

OSENI, T. O.; ALIYU, I. G. Effect of row arrangements on sorghum-cowpea intercrops in the semi-arid savannah of Nigeria. International Journal of Agriculture and Biology, v. 12, p. 137-140, 2010. 
SHAHI, U.P.; DESHRAJ, A.; DVIWEDI, B. P.; DHYANI, A.; KUMAR; KISHORE, R. Yield maximization of late sown wheat through INM approach and its consequences on physico-chemical properties of soil. Green Farming, v. 7, p. 638-641, 2016.

SPARKS D. L.; PAGE, A. L.; HELMKE, P. A.; LEOPPERT, R. H.; SOLTANPOUR, P. N.; TABATABAI, M. A.; JOHNSTON, G. T.; SUMNER, M. E. Methods of Soil Analysis. Madison, WI: Soil Science Society of America, 1996.

TAKIM, F. O. Advantages of maize-cowpea intercropping over sole cropping through competition indices. Journal of Agriculture and Biodiversity Research, v. 1, p. 53-59, 2012.

YAN, L.; HUI, L.; JINJING, Z.; ZHIDAN, Z.; PING, Z.; QIANG, G.; WENXI, L. Response of organic nitrogen in black soil to long-term different fertilization and tillage practices in Northeast China. Soil \& Water Research, v. 11, p. 124-130, 2016. https://doi.org/10.17221/32/2015-SWR

YANG, R.; PENG, W.; MAHA, F.; ELBALOULA; ZHENXIN, G. U. Effect of germination on main physiology and biochemistry metabolism of sorghum seeds. Bioscience Journal, v. 32, p. 378-383, 2016. https://doi.org/10.14393/BJ-v32n2a2016-30895

YOUNIS, A.; RIAZ, A.; WASIM, M.; KHAN, M. A.; NADEEM, M. (2010). Production of quality croton (Codiaeum variegatum) plants by using different growing media. American-Eurasian Journal of Agricultural and Environmental Sciences, v. 7, p. 232-237, 2010.

ZHANG, F. S.; LI, L. Using competitive and facilitative interactions in intercropping systems enhances crop productivity and nutrient-use efficiency. Plant and Soil, v. 248, p. 305-312, 2003. https://doi.org/10.1023/A:1022352229863 